\title{
Social Engagement: A means to Brand Building
}

\author{
Shailashri V.T. ${ }^{1}$ and Anumesh Kariappa ${ }^{2}$ \\ ${ }^{1}$ Research Professor, College of Management and Commerce, Srinivas University, Mangalore, \\ India. E-Mail: shailashrivt@gmail.com, \\ ${ }^{2}$ Assistant Professor, College of Management and Commerce, Srinivas University, Mangalore, \\ India. E-Mail: anumesh5@rediffmail.com.
}

Area of the Paper: Business Management.

Type of the Paper: Research Analysis.

Type of Review: Peer Reviewed as per $|\mathrm{C}| \mathrm{O}|\mathrm{P}| \mathrm{E} \mid$ guidance.

Indexed In: OpenAIRE.

DOI: http://doi.org/10.5281/zenodo.4248273

Google Scholar Citation: IJCSBE.

\section{How to Cite this Paper:}

Shailashri V.T. and Kariappa Anumesh (2020). Social Engagement: A means to Brand Building. International Journal of Case Studies in Business, IT, and Education (IJCSBE), 4(2), 212-219. DOI: http://doi.org/10.5281/zenodo.4248273

International Journal of Case Studies in Business, IT and Education (IJCSBE)

A Refereed International Journal of Srinivas University, India.

(C) With Authors.

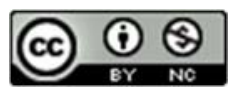

This work is licensed under a Creative Commons Attribution Non-Commercial 4.0 International License subject to proper citation to the publication source of the work.

Disclaimer: The scholarly papers as reviewed and published by the Srinivas Publications (S.P.), India are the views and opinions of their respective authors and are not the views or opinions of the S.P. The S.P. disclaims of any harm or loss caused due to the published content to any party. 


\title{
Social Engagement: A means to Brand Building
}

\author{
Shailashri V.T. ${ }^{1}$ and Anumesh Kariappa ${ }^{2}$ \\ ${ }^{1}$ Research Professor, College of Management and Commerce, Srinivas University, Mangalore, \\ India. E-Mail: shailashrivt@,gmail.com \\ ${ }^{2}$ Assistant Professor, College of Management and Commerce, Srinivas University, Mangalore, \\ India. E-Mail: anumesh5@,rediffmail.com
}

\begin{abstract}
Corporate Social Responsibility (CSR) is a norm and a buzzword in today's business world. With the advent of the COVID-19 it has gained more prominence, and taken different forms and structure. Thought the Companies Act 2013 makes it mandatory to spend 2\% of profit earned, bigger organizations are going beyond these requirements and creating a brand for themselves in the market. This has made organizations move form merely contributing to the society to gradually engaging to the societal concerns thus giving scope to the emerging concept of Social Engagement. By making a presence in the market by contributing in terms of rural development, educational purpose, hygiene and health and many other forms, bigger organizations are an important helping source to the societal development. This paper makes a broad attempt to understand and evaluate the current status, nature and scenario of CSR or Social Engagement in India. Further the study probes into identifying the best companies listed in Bombay stock exchange (BSE) and (NSE) National stock exchange in terms of CSR contributions. Identifying the companies has further advanced in finding the major areas of contribution. Education and skill development, hygiene and health improvements, and rural transformation are the key and major focus areas which major companies work on with respect to CSR. The last section of analysis of this paper makes an earnest analysis of the concept of CSR in terms of a qualitative Model known as ABCD Model. The analysis in the study reveals many advantages and benefits by CSR related initiatives to the Organization. Thus, it is evident and generally could be concluded that Social Engagement is a way towards building a better brand for an organization.
\end{abstract}

Keywords: Corporate Social Responsibility, Social Engagement, Brand Building, Indian Companies, Education, Health, Rural Transformation.

\section{INTRODUCTION:}

Social Engagement refers to the degree of involvement in community or social activities. Prohaska, Anderson ((2012) meant this term to denote one's participation in social groups [1]. Avison, McLeod and Pescosolido (2007) defined social engagement as "the extent where an individual participates in many and in a broad range of social roles and relationships." The key constituents of social engagement include doing a social activity, interaction between many entities, social exchange, and the willingness and eagerness to voluntarily initiate and take up an activity or a course of action that may benefit another [2]. In general, it could be concluded as the involvement or participation one may have or has with the society or community. Social engagement in the context of this paper stresses upon the corporate social responsibility (CSR) initiatives the companies are engaged in.

Corporate Social Responsibility (CSR) is a way a corporate organization becomes socially accountable. CSR activities initiated by organizations strives to have a positive influence and impact on the environment, public and general economy at large. As social consciousness is increasing employees, customers, board members and other stake holders look forward to be connected and associated with organizations which have made an impact and imprint on the society. Similarly, the organization too has many benefits by connecting to and with the society and building a strong brand. A comprehensive CSR initiative by each of the organization will help in building and creating and generating a good corporate citizenship [3]. The CSR activities undertaken by organizations can be broadly classified as follows: 


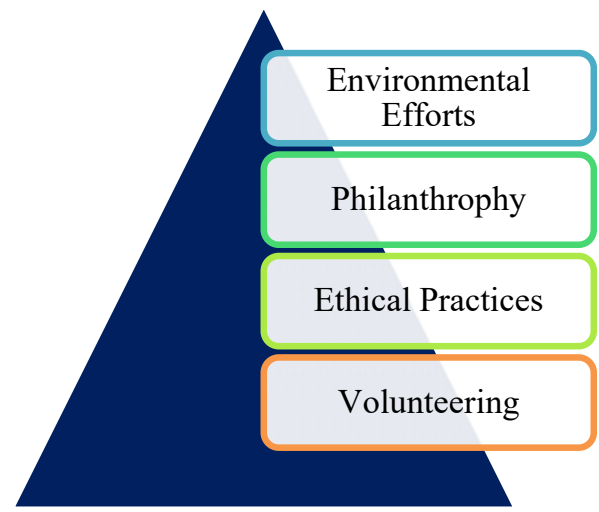

Fig. 1 : Classification of CSR

- Environmental Efforts: Organizations whatever their size, nature and conduct of business have a tremendous impact on environment. Every organization is responsible in trying to reduce the carbon footprints which will benefit and is good for the society.

- Philanthropy: The organizations can donate money, products and services to the society. Many organizations have no dearth of recourses and this can be donated for a better and good cause which can create and make a lot of difference to the needy.

- Ethical Practices: By following and adhering to the labor laws of a country and doing business in an ethical method an organization can be socially engaged.

- Volunteering: Organizations can initiate and volunteer in various community related activities by encouraging employees or teams from the organization to spare ones time or money without expecting any returns.

\section{REVIEW OF RELATED WORK:}

The table1 below reveals that tremendous research work in the area of CSR with respect to companies has been undertaken between the years 2015 and 2016. The review of some good work reveals that CSR has a strong and positive impact on the internal customers that is employees, external customers and also an impact on financial aspects of an enterprise. The previous study also highlights the size of the company matters in contributing and implementing CSR initiatives.

Table 1: Corporate social work in Indian Companies.

\begin{tabular}{|l|l|l|l|}
\hline $\begin{array}{l}\text { Serial } \\
\text { Number }\end{array}$ & Theory & Focus & Reference \\
\hline 1 & $\begin{array}{l}\text { Strong relationship between } \\
\text { CSR and employees exists. }\end{array}$ & $\begin{array}{l}\text { Information } \\
\text { Technology } \\
\text { Companies. }\end{array}$ & $\begin{array}{l}\text { Dhanesh G.S } \\
2015 \text { [4]. }\end{array}$ \\
\hline 2 & $\begin{array}{l}\text { Studied in detail the } \\
\text { regulations followed by } \\
\text { Public sector companies in } \\
\text { terms of CSR initiatives. }\end{array}$ & $\begin{array}{l}\text { Public } \\
\text { companies. }\end{array}$ & $\begin{array}{l}\text { Singh, S. \& Sharma, A. } \\
(2015) \text { [5]. }\end{array}$ \\
\hline 3 & $\begin{array}{l}\text { Liability towards CSR } \\
\text { remains the same after the } \\
\text { inclusion of CSR section 135, } \\
\text { and is more flexible to } \\
\text { companies. }\end{array}$ & $\begin{array}{l}\text { Maharatana } \\
\text { Companies. }\end{array}$ & $\begin{array}{l}\text { Athma and Yaragorola } \\
2015 \text { [6]. }\end{array}$ \\
\hline 4 & $\begin{array}{l}\text { Positive impact of CSR on } \\
\text { Financial indicators of the } \\
\text { company. }\end{array}$ & $\begin{array}{l}\text { Navarathna } \\
\text { Companies. }\end{array}$ & $\begin{array}{l}\text { Das and Bhunia 2015 } \\
\text { [7]. }\end{array}$ \\
\hline
\end{tabular}




\begin{tabular}{|l|l|l|l|}
\hline 5 & $\begin{array}{l}\text { The size of the organization } \\
\text { matters towards contributing } \\
\text { to CSR. }\end{array}$ & $\begin{array}{l}\text { Large and small scale } \\
\text { firms. }\end{array}$ & $\begin{array}{l}\text { Chatterjee and Mitra } \\
(2017)[8] .\end{array}$ \\
\hline
\end{tabular}

\section{OBJECTIVES:}

This theoretical and conceptual paper is based upon and on the disclosures made by companies. Inferences are drawn by analyzing the true figures and facts disclosed and conclusions are drawn thereof.

1. To understand the present status of CSR (Corporate Social Responsibility) in India.

2. To identify, understand and comprehend the best performing organizations towards CSR contribution in India.

3. To analyze major contributions to CSR using a qualitative tool called ABCD model.

\section{PRESENT STATUS OF CSR IN INDIA:}

The Companies Act 2013 makes it compulsory for every organization to spent 2 percent of their average net profit earned on CSR [9]. An analysis of companies listed in Bombay stock Exchange (BSE) and National Stock Exchange spending on CSR has revealed the following information.

1. The number of companies spending on CSR has drastically increased year on year. The below graph depicts the same.

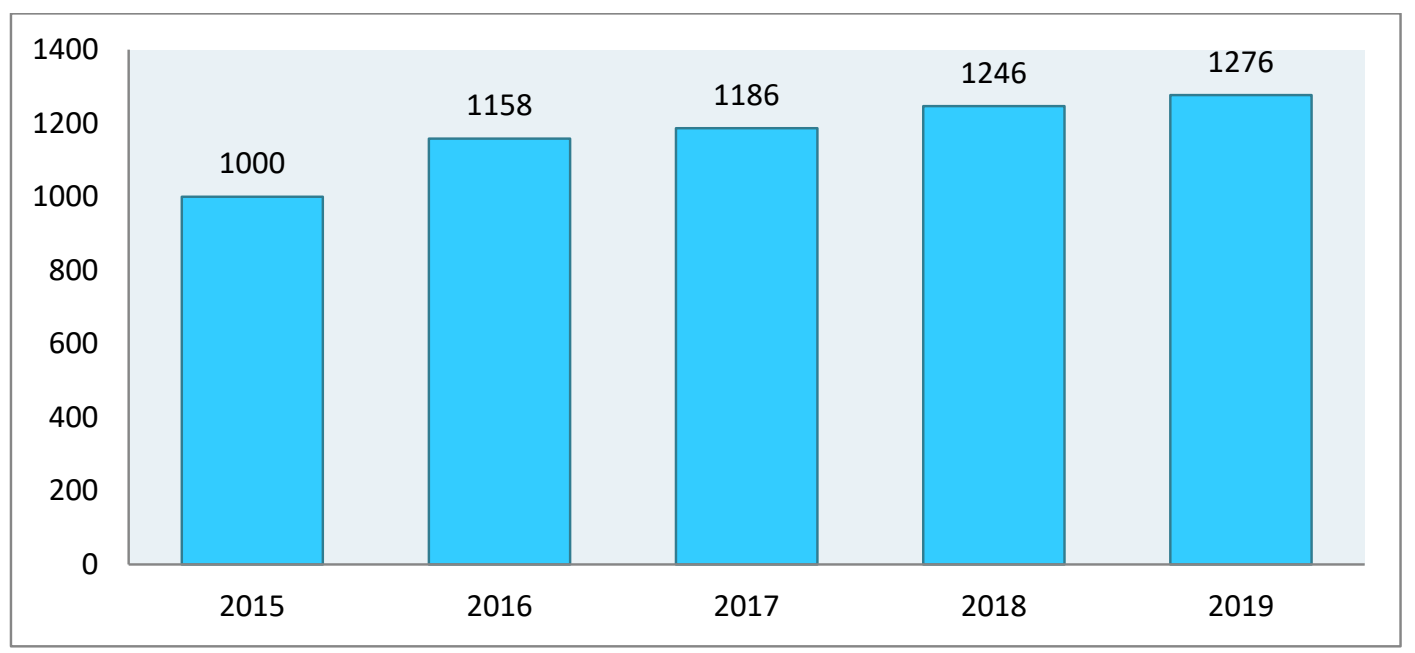

Fig. 2: Number of companies spending on CSR

Of the total of 4,817 companies listed in Bombay stock Exchange (BSE) and National Stock Exchange (NSE) in the year 2019, 1276 organizations reported to have spent an aggregate of Rs 11,392 crores on CSR activities taking the growth of expenditure to an average of $14 \%$ year on year.

2. Total amount as a percentage (\%) of profit which has been spent on CSR remains at $2.01 \%$ which satisfies the requirements of the Companies Act 2013.

3. It is noticed that education and skill development, health and hygiene and rural development were the priority areas focused by companies who spend on CSR for the financial year 2019.

Table 2: Priority areas of CSR with the Number of Companies.

\begin{tabular}{|l|l|l|}
\hline Serial Number & Sector & Number of Companies \\
\hline 1 & Education and skill development. & 1030 \\
\hline 2 & Health and hygiene. & 881 \\
\hline 3 & Rural development. & 310 \\
\hline
\end{tabular}


The table 2 above depicts the areas which organizations take up for Corporate Social Responsibility. Most of the well-known companies take up education sector as a priority. Rendering education in terms of adoption of schools, computer literacy programs, and basic literacy programs irrespective of the age factor is gaining importance. The second and next area that has gained priority is health and hygiene. Basic awareness programs and fundamental hygiene and health aspects are given importance in the present times. The Indian masses live in rural areas and have a livelihood. Developing the rural area will definitely enhance the overall growth of India. Thus, rural development also remains on the top of the priority list [10].

4. Relatively high spending by the Public Sectors.

Table 3: Spending by Public and Private Sector on CSR.

\begin{tabular}{|l|l|l|l|}
\hline Serial Number & Sector & $\begin{array}{l}\text { Number of } \\
\text { Companies }\end{array}$ & $\begin{array}{l}\text { Amount on } \\
\text { CSR.Rs (cr) }\end{array}$ \\
\hline 1 & Public & 113 & 3224 \\
\hline 2 & Private & 1104 & 7709 \\
\hline 3 & Private Foreign & 59 & 459 \\
\hline
\end{tabular}

Table 3 clearly shows the number of Public sector players listed is much lesser when compared to the Private sectors. The amount spent on CSR when looked upon closely draws a conclusion that public sector companies spend a relatively higher amount than private sectors though they are more in number.

5. Maharashtra remained to have a greater number of companies listed and at the same time had a major share in contributing to CSR activities in India.

From the above discussion it is seen that organizations are feeling the need to become socially engaged no matter, the size of the organization, the type of ownership and the sector they belong to. The positive benefits of contributing to CSR are understood by almost all companies [11-12].

\section{UNDERSTANDING THE CONCEPT OF CSR BY THE TOP COMPANIES IN INDIA:}

Today's well-known industrial giants make it a priority to contribute to corporate social responsibility (CSR) activities. By socially engaging organizations become well acquainted and known to internal as well as external stake holders who are directly or indirectly connected to the organizational helm of affairs. Usually CSR activities are taken up under separate leadership and team of members are exclusively dedicated to this purpose.

Table 4: Top Five Companies in terms of contribution to CSR.

\begin{tabular}{|l|l|l|l|l|}
\hline Company Name & $\begin{array}{l}\mathbf{2 0 1 9 -} \\
\mathbf{2 0 2 0} \\
\text { Rs in } \\
\text { crores } \\
\text { Proposed }\end{array}$ & $\begin{array}{l}\mathbf{2 0 1 8 - 2 0 1 9} \\
\text { Rs in crores }\end{array}$ & $\begin{array}{l}\mathbf{2 0 1 7 - 2 0 1 8} \\
\text { Rs in crores }\end{array}$ & $\begin{array}{l}\text { 2016-2017 } \\
\text { Rs in crores }\end{array}$ \\
\hline $\begin{array}{l}\text { Reliance Industries } \\
\text { Limited }\end{array}$ & 892.36 & 848.32 & 746.04 & 659.20 \\
\hline TCS Limited & 684.68 & 434 & 400 & 379 \\
\hline $\begin{array}{l}\text { Oil and Natural Gas } \\
\text { Corporation Limited }\end{array}$ & 627 & 614 & 503.4 & 525 \\
\hline $\begin{array}{l}\text { Indian Oil Corporation } \\
\text { HDFC Bank Limited }\end{array}$ & 560 & 490.6 & 331 & 213.99 \\
\hline
\end{tabular}

Table 4 shows the actual expenditure by companies on CSR activities. Year on year it is seen to be increasing which clearly is an indication for the need to be socially engaged. Reliance Industries Limited tops the list in the contribution to CSR followed by TCS limited and HDFC bank limited stands at position five in terms of 
CSR contribution for the year 2019-2020 from among the enterprises that are listed in the NSE and BSE.

5.1 Reliance Industries Limited: As per the disclosures Reliance industries spends the highest on CSR. The CSR expenses in crores is Rs746.04cr (2017-2018), Rs848.32 (2018-2019) and Rs 892.36cr (2019-20) respectively for three years. The company has a tremendous impact and has been able to touch upon the lives of several millions of people in almost every village. The company took up several initiatives leading to rural transformation, basic health improvements, disaster management, and education, encouragement of sports activities, culture and art, heritage renewal and urban renewal. The contribution of Reliance at and during times of the pandemic is commendable.

5.2 Tata Consultancy Services Limited: TCS is one part of the Tata Group of companies, and is a known IT services provider in the whole of Asia in terms of service quality, innovation and CSR initiatives. It is among the highest employers of IT and provides information technology related solutions and services to banking, telecom, media education and other services. TCS has contributed to the society in special projects like Water conservation, Health Sanitation and Hygiene, and educational development. One of their wellknown educational program is called the laboratory on bike where by basic science experiments are conducted to the government school children in and around Bangalore.

5.3 Oil and Natural Gas Corporation: ONGC is a public sector enterprise which was initially started under the guidance and leadership of late Jawaharlal Nehru. It is a globally recognized natural gas enterprise and also under the Forbes global 2000 companies. The company is again well known for its corporate governance and has unique CSR initiatives like cleaning of rivers, financial support to hospitals, construction of school and hostel building, promotion of Sanskrit language, skill development and women empowerment. For the fiscal year 2019-2020the proposed budget for CSR stands at Rs 627 crores.

5.4 Indian Oil Corporation: IOC is again a globally admired company and India's largest commercial entity. This company is involved in the entire lengthy process of Hydro-carbon value chain which includes digging for oil to marketing and selling of crude oil and petroleum related products. IOC has a group foundation which in association with the Archeological society tries to preserve and safeguard the National Heritage of the country. IOC initiates sports scholarships, skill development, donations to Schools and also the benefits of yoga. The company is estimated to spend 560 crores for the year 2019-2020.

5.5 HDFC Bank Limited: HDFC is a bank of Indian origin and financial service provider which is headquartered in Mumbai. It is a well-known private sector bank and known for its innovative services in banking field of our country. It is also the best known in terms of market capitalization and has a variety of CSR initiatives to its credit. It is known for its holistic rural development and transformation. Poverty alleviation and environmental sustainability are the other core areas which are focused by the bank as social engagement initiatives. The contribution towards social engagement, CSR has grown from Rs $305.4 \mathrm{cr}$ in the year 2016-17 to Rs 443cr as of 2018-2019.

\section{ABCD ANALYSIS FOR COMPANIES CONTRIBUTING TO CSR :}

Here is an effort to analyze the companies contributing to CSR with a latest qualitative tool in Business management called $\mathbf{A B C D}$ analysis, in which $\mathbf{A}=\mathbf{A d v a n t a g e s ,} \mathbf{B}=\mathbf{B}$ enefits, $\mathbf{C}=$ Constrains $\mathbf{D}=$ Disadvantages [13-17].

\subsection{Advantages by contributing to CSR.}

1. The organization can have a better brand building platform.

2. Companies will be able to increase the sales revenue.

3. The organization can grow and expand its business.

4. Organizations can have better customer loyalty.

5. Organizations can have better financial performance.

\subsection{Benefits by contributing to CSR.}

1. Organizations can attract customers.

2. Organizations can create an employer brand and be able to attract the best of employees.

3 . Employees can be retained in the organization.

4. Organizations will be able to get better access to financial capital.

5. Company will be in a position to meet all the stakeholders demand. 


\subsection{Constrains by contributing to CSR.}

1. It is an expensive affair to the organization.

2. Organizations may not be able to choose a relevant CSR activity which may benefit the society.

\subsection{Disadvantages by contributing to CSR.}

1. It incurs cost to the company.

2. Might lead to conflict of interest among all stakeholders on determining which CSR imitative.

\section{RECOMMENDATION :}

From the detailed analysis of the concept of CSR it is identified that a large number of organizations listed in the Indian Exchange Market are contributing towards the society. It is seen that the priority and contribution areas concentrated by the companies remain the same. Education, health and rural development are the focus areas. The study suggests and indicates that organizations can contribute in other fields too as there could be a balanced growth. Youth empowerment can be more considered as India is a young nation and this may lead to further development and progress in the country in the near future. Skill enhancement is also an area that can be looked upon and given priority. Employment generation needs to be considered seriously to develop the country. Companies can fund and help in self-employment and promote local growth.

\section{CONCLUSION :}

The laws being enacted in the country companies have an organizational mindset to contribute to the societal concerns. The study reveals and shows there is a slow and steady progress in terms of monetary contribution, number of beneficiaries and geographical stretch and reach. As the good outcomes are more compared to constrain and disadvantages of CSR definitely it has an overall positive impact. Organizations also see corporate social responsibility or social engagement as a means to build a good employer brand and focus on customer loyalty too. The brand image of the organization enhances with respect to its internal and external stakeholders. Thus, organizations should not only keep the profit motive always, they can generously contribute towards the society and help out in the making of a developed country.

\section{REFERENCES :}

[1] Thomas, Prohaska, Anderson, Robert, H. Binstock (2012). Public Health for an Aging Society. JHU Press. pp. 249-252. ISBN 978-1-4214-0535-3.

[2] William, R. Avison, Jane, D. McLeod, Bernice, A. Pescosolido (2007). Mental Health, Social Mirror. Springer. pp. 333. ISBN 978-0-387-36319-6.

[3] Skye, Schooley, Staff, What is corporate social responsibility? Retrieved from https://www.businessnewsdaily.com/4679-corporate-social-responsibility.html, on 25, September 2020.

[4] Dhanesh, G. S. (2014). CSR as organization-employee relationship management strategy: A case study of socially responsible information technology companies. Management Communication 28(1), 130149.

[5] Singh S. \& Sharma, A. (2015). Corporate social responsibility practices in India: Analysis of Public companies. International Journal of Business Quantitative Economics \& Applied Management Research, 1(11), 33-44.

[6] Singh, P. Athma (2015). Corporate social responsibility: Its roles and challenges in Indian context. International Journal of Applied Research, 2(1), 23-29.

[7] Das and Bhunia (2015). How does CSR respond to financial performance, American Journal of Management and Humanities,1(3),8-21.

[8] Chatterji, Mishra. S., \& Damodar S. (2017). Does CSR, social responsibility influence performance of Indian companies. Journal of business ethics, 95(4), 571-601.

[9] Maria. A. (2013). India's $2 \%$ CSR Law - The first country to go backwards. Economic and Political weekly, 48(38), 23-25.

[10] Timane R. \& Tale T. (2012). A Study of Corporate Social Responsibility (CSR) in India. International Journal of Research in IT \& Management, 2(12), 67-80. 
[11] McDonald L. M. \& Rundle Thiele S. (2008). Corporate social responsibility (csr) and bank customer satisfaction: A research agenda. International Journal of Bank Marketing, 26(3), 170 - 182.

[12] Green, T. \& Peloza, J. (2011). How does corporate social responsibility (CSR) create worth for consumers? Journal of Consumer Marketing, 28(1), 48-56.

[13] Aithal, P. S. \& Suresh Kumar, P. M., (2016). ABC Model of Research Productivity and Higher Educational Institutional Ranking. International Journal of Education and Management Engineering (IJEME), 6(6), 74-84.

[14] Aithal, P. S., Shailashree, V. T. \& Suresh Kumar, P. M. (2016). Analysis of NAAC Accreditation System using $\mathrm{ABCD}$ framework. International Journal of Management, IT and Engineering (IJMIE), $6(1), 30-44$.

[15] Aithal, P. S., Shailashree, V. T. \& Suresh Kumar, P. M., (2016). Analysis of ABC Model of Annual Research Productivity using ABCD Framework. International Journal of Current Research and Modern Education (IJCRME), 1(1), 846-858.

[16] Aithal, P. S. \& Suresh Kumar, P. M. (2016). Analysis of Choice Based Credit System in Higher Education. International Journal of Engineering Research and Modern Education (IJERME), 1(1), 278284.

[17] Aithal, P. S., Shailashree, V. T. \& Suresh Kumar, P. M. (2016). Application of ABCD Analysis Framework on Private University System in India. International Journal of Management Sciences and Business Research (IJMSBR), 5(4), 159-170. 